\title{
Transmission of Archaic Greek Sympotic Songs: From Lesbos to Alexandria
}

\section{Citation}

Nagy, Gregory. 2004. "Transmission of Archaic Greek Sympotic Songs: From Lesbos to Alexandria." Critical Inquiry 31 (1) (September): 26-48. doi:10.1086/427301.

\section{Published Version}

doi:10.1086/427301

\section{Permanent link}

http://nrs.harvard.edu/urn-3:HUL.InstRepos:14531702

\section{Terms of Use}

This article was downloaded from Harvard University's DASH repository, and is made available under the terms and conditions applicable to Other Posted Material, as set forth at http:// nrs.harvard.edu/urn-3:HUL.InstRepos:dash.current.terms-of-use\#LAA

\section{Share Your Story}

The Harvard community has made this article openly available.

Please share how this access benefits you. Submit a story.

Accessibility 


\section{Transmission of Archaic Greek Sympotic Songs: From Lesbos to Alexandria}

\section{Gregory Nagy}

[[This essay was originally published in 2004 in Critical Inquiry 31:26-48. In this online version, the original page-numbers of the printed version are indicated within braces (" $\{$ " and " $\}$ "). For example, "\{26|27\}" indicates where p. 26 of the printed version ends and p. 27 begins.]]

This inquiry centers on the transmission of sympotic songs attributed to Alcaeus of Mytilene, a city on the island of Lesbos. The starting point of transmission is the "original" setting of songs sung at symposia in Lesbos in the heyday of Alcaeus, around $600 \mathrm{BCE}$. Subsequent points include the "secondary" settings of (1) symposia in the city of Athens around the same time and thereafter; (2) revivalist educational contexts in Athens and Lesbos during the 300s BCE; (3) antiquarian academic contexts in Alexandria, center of Hellenistic scholarship during the 200s.

The "original" setting of Alcaeus' sympotic songs has been studied in an article by Wolfgang Rösler on the function of the poetic "I" in archaic Greek songmaking. ${ }^{1}$ Elsewhere, I have studied the pertinence of Rösler's work to the general question of genre and occasion and to the specific question of Pindar's poetic "I" in his epinician or victory songs. ${ }^{2}$ Here I propose to narrow and deepen my study of the general question and to switch directions by pursuing the specific question of the poetic "I" not in the epinician songs of Pindar but in the sympotic songs of Alcaeus and beyond.

Rösler objects to what he calls an "immanentistic" interpretation of archaic songmaking traditions. ${ }^{3}$ From such an immanentistic point of view, references to the self are seen as

\footnotetext{
${ }^{1}$ Rösler 1985.

${ }^{2}$ See N 1994/5b.

${ }^{3}$ Rösler 1985:137.
} 
exercises in creating a Rollencharakter, as if the poetic " $\mathrm{I}$ " were merely a function of poetic conventions. ${ }^{4}$ This "fictional I" is for Rösler the opposite of an "autobiographical I"-to which he also objects. As he navigates between these two opposites, portraying them as Scylla $\{26 \mid 27\}$ and Charybdis, he aims for a compromise solution that can best be described as a "historical I." 5

Building on Rösler's insights, I too aim at a middle course between the "fictional I" and the "autobiographical I." But for me it is not so much a "historical I" but a "re-enacting I." In other words, the "I" is a function of mimesis, to the extent that this word had meant primarily "reenact' or 're-produce' and only secondarily 'imitate'.

Let us follow up on the implications of applying the archaic model of mimesis to the middle ground between "autobiographical I" and "fictional I" in archaic Greek songmaking. The idea of a "re-enacting I" accommodates the idea of reality as vaguely implicit in the term "autobiographical" but it recognizes, at the same time, that the self-expression as reflected in the "auto-" of "autobiographical" observes the rules of the medium within which the expression takes place. The main problem with the "autobiographical I" is this: if indeed the self is expressed by way of a medium that controls the self-expression, to what extent can we think of that self as a genuine individual who is speaking about his or her genuine experiences? Or, to go to the other extreme, to what extent can we think of the self as fictional?

At this other extreme, the main problem is different: it centers on the very concept of fictional in the construct of a "fictional I" in archaic Greek lyric. A "fictional I" is a matter of mimesis as mere imitation, to be contrasted with my proposed construct of a "re-enacting I." A

\footnotetext{
${ }^{4}$ Rösler p. 132.

${ }^{5}$ Rösler p. 138. Cf. Yerly 1992:25n49.

${ }^{6} \mathrm{~N} 1994 / 5 b$.
} 
term more apt than "fictional" $\{27 \mid 28\}$ might be "generic," which I propose to retain provided we continue to understand genre as a formal device to create or re-create the occasion. ${ }^{7}$

With this theoretical background, we are ready to confront the question: how are the terms "re-enacting I" or "generic I" applicable to the poetic "I" of Alcaeus? For answers, we must start with the historical background of Alcaeus as a representative of sympotic songmaking traditions in the city of Mytilene on the island of Lesbos.

The primary textual evidence for the sympotic songmaking traditions of archaic Lesbos centers on this figure Alcaeus. Our initial impression is that the occasions of Alcaeus' songs are genuine historical events, and there seems at first to be hardly even any question of genrebeyond the need to say that these songs are generally known under the vague heading of "lyric" and that they seem appropriate to a drinking-party, that is, to a symposium. A closer examination, however, will indeed raise important questions about genre-and perhaps even about the reality or historicity of the occasions or situations represented by the songs of Alcaeus.

Pursuing the concept of "generic I," with the goal of reaching a more precise concept of a “re-enacting I," I am ready to accept Rösler's dictum that the identity of Alcaeus as a lyric poet is a function of his social group, his hetaireia: "ohne Hetairie kein Lyriker Alkaios." Hence the germinal notion of poet and group in Rösler's 1980 book, Dichter und Gruppe. For the moment, let us adopt his definition of Alcaeus' hetaireia as the social group that the poet seems to be addressing in his songs, the formal setting of which is the symposium. ${ }^{9}$

As Rösler stresses throughout his book on Alcaeus, the poet's songs for his hetaireia were meant not to be read but to be performed, in the specific historical context of symposia actually

\footnotetext{
${ }^{7}$ Cf. N 1990a:9, 362.

${ }^{8}$ Rösler 1980:40.

${ }^{9}$ Ibid.
} 
held in the city-state of Mytilene on the island of Lesbos. ${ }^{10}$ Moreover, given the traditional date assigned to the time when Alcaeus flourished, around $600 \mathrm{BCE}$, Rösler argues that the songs of this poet must have been the product of an era so early that the technology of writing was not yet generally used for either the composition or even the recording of songs.

So far, Rösler's reconstruction of the historical circumstances of Alcaic songmaking is intuitively compelling, especially in light of the early dating of Alcaeus. A problem arises, however: how in fact were the songs of Alcaeus preserved, if indeed $600 \mathrm{BCE}$ or thereabouts is too early a date to posit for the regular use of writing as a way to enshrine a corpus of compositions? Rösler's solution is to posit a phase of oral transmission as well as composition, through the intermediacy of Alcaeus' hetaireia. Another problem then arises, however: $\{28 \mid 29\}$ how in that case are we to account for the ad hoc or occasional characteristics of Alcaeus' songs? ${ }^{11}$ Rösler explains that the artistry of Alcaeus, surpassing in quality the artistry of any other member of his hetaireia, would have become specially valued and highlighted by the oral tradition itself, so that Alcaic songs could be transmitted as distinct from other songs.

Such an explanation, however, is not supported by the comparative evidence of fieldwork in living oral traditions: no matter how good or bad a given song may be-if we apply the criteria of "good" and "bad" not from our point of view but from the internal standpoint of the given oral tradition itself-the next performer may still make that song "worse" or "better," depending on that performer's skills. The deterioration or amelioration may depend even on circumstances beyond the performer's control, as in the case of audience response. ${ }^{12}$

\footnotetext{
${ }^{10}$ The question remains: performed by whom? From Rösler's point of view, the performer is Alcaeus himself. From the point of view that I am about to develop, the answer is more complex.

${ }^{11}$ Examples: in Alcaeus F 129, Alcaeus puts a curse on Pittakos; in F 130, he speaks from exile; in F 141, he predicts that the city will soon be overthrown.

${ }^{12}$ For a wide-ranging review, see Lord 1960 and 1991.
} 
Moreover, the contents of a given song in an oral tradition will change with each composition-in-performance, even in circumstances where the song proclaims that its own unchangeability is a prerequisite for its own perpetuation. ${ }^{13}$ In other words, the occasionality of a song in oral tradition induces change even when change is ideologically denied. ${ }^{14}$ Such a traditional mentality is evident in a passage from Theognis of Megara, where the persona of Theognis claims that he is placing a sphragis 'seal' upon his words as he identifies himself by name:

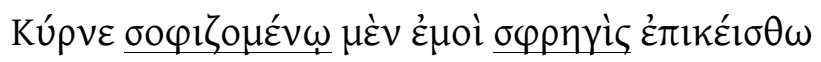

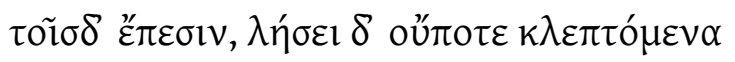

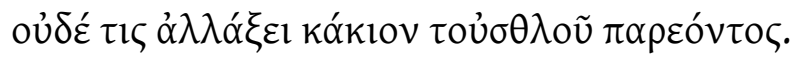

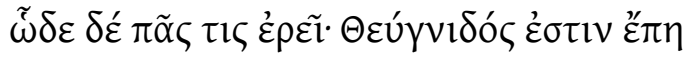

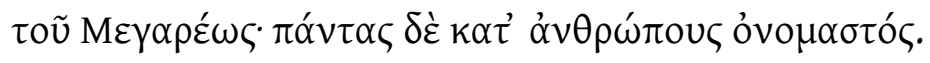

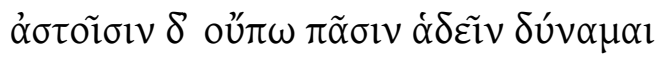
Kyrnos, let a seal [sphragis] be placed by me, as I practice my skill [sophia], upon these my words. This way, it will never be undetected if they are stolen, and no one can substitute something inferior for the genuine thing that is there. And this is what everyone will say: "These are the words of Theognis of Megara, whose name is known among all mortals." But I am not yet able to please [= verb handanein] all the townspeople [astoi].

Theognis 19-24

In a previous work, I have offered this argument about the "seal" of Theognis: $\{29 \mid 30\}$

\footnotetext{
${ }^{13}$ Examples in N 1996b:14-16, 40-41.

${ }^{14}$ Ibid.
} 
Like the code of [a] lawgiver, the poetry of Theognis presents itself as static, unchangeable. In fact, the sphragis 'seal' of Theognis is pictured as a guarantee that no one will ever tamper with the poet's words. Outside this ideology and in reality, however, the poetry of Theognis is dynamic, subject [like the law code of Lycurgus] to modifications and accretions that are occasioned by an evolving social order. And the poet is always there, observing it all-despite the fact that the events being observed span an era that goes well beyond a single lifetime. ${ }^{15}$

With his "seal," the man who calls himself Theognis is authorizing himself, making himself the author. ${ }^{16}$ The author's authority is made evident by his sophia, the 'skill' of decoding or encoding poetry. ${ }^{17}$ With his sophia, the author lays claim to a timeless authority, which resists the necessity of changing just to please the audience of the here and now, who are described as the astoi 'townspeople'. "18 "The author must risk alienation with the audience of the here and now in order to attain the supposedly universal acceptance of the ultimate audience, which is the cumulative response of Panhellenic fame." ${ }^{19}$ The clearest example of such alienation is the poetic self-representation of the generic "suffering righteous" who is alienated from the hereand-now but integrated with the ultimate form of society which is presumed as the ultimate audience of the poetry (Theognis 1209-1210). ${ }^{20}\{30 \mid 31\}$

\footnotetext{
${ }^{15}$ N 1985:33. Cf. Ford 1985:85: "Theognis is not simply the name of a marvelous performer but the lock and key fixing a body of poetry and guaranteeing its provenience."

${ }^{16} \mathrm{~N}$ 1996a:222. Cf. Batchelder 1994 on the poetics of the sphragis 'seal' in the Electra of Sophocles.

${ }^{17}$ On sophos 'skilled' as a programmatic word used by poetry to designate the 'skill' of a poet in encoding the message of the poetry, see N 1990a:148; also p. 374n190: "A successful encoder, that is, poet, is by necessity a successful decoder, that is, someone who has understood the inherited message and can therefore pass it on. Not all decoders, however, are necessarily encoders: both poet and audience are decoders, but only the poet has the authority of the encoder."

${ }^{18}$ In this and related contexts, astoi 'townspeople' seems to be the programmatic designation of local audiences, associated with the special interests of their own here and now. See N 1990a:273-275.

${ }^{19} \mathrm{~N} 1996 \mathrm{a}: 222$. On the theme of the alienated poet, see $\mathrm{N} 1985: 30$ and following.

${ }^{20} \mathrm{~N} 1985: 76-81$. In N 1993, I argue at length that Alcaeus F 129 and F 130 are other examples of this theme.
} 
Rösler himself insists on the occasionality of Alcaeus' songs, which appear to be tied to a fixed time and place, addressing specific historical situations. But there is also the occasionality of singing these same songs in later times and even in different places. How, then, we may ask, can Alcaeus remain the "same" if this sameness depends on an oral tradition to transmit his songs-an oral tradition that we may expect to be ever-changing? The answer, as I will now argue, is to be found in the principle of the "re-enacted I."

If indeed the performance of song at a symposium was the primary medium of Alcaeus, we must consider carefully whatever counts as a conventional subject matter for performance in the context of this medium. In a symposium, I submit, the conventions of performance for a hetaireia are driven by an archaic mentality of mimesis, where the performing I is inherently a "re-enacted I." Here I return to my initial point, that mimesis was re-enactment. Moreover, mimesis was ritual re-enactment, and I stress that this word "ritual" is an apt designation of such institutionalized occasions as the symposium in archaic Greece. ${ }^{21}$ When one performs for the hetaireia in a symposium a role that serves as a self-expression of the hetaireia-a role that reinforces the very identity of the hetaireia-then one is performing in a ritual context.

It is important to add, however, that the hetaireia is diachronic-and so too, for that matter, is the "re-enacted I" of Alcaeus:

The persona of Alcaeus may be adaptable through time, fitting a wide variety of situations-both positive and negative-affecting the very idea of hetaireia. Just as the society reflected by Alcaeus-let us continue to call it his hetaireiachanges over time, so also the persona of Alcaeus may change along with it. ${ }^{22}$

\footnotetext{
${ }^{21}$ On the symposium as ritual, see Schmitt-Pantel 1990, especially p. 21; also Murray 1983, 1990; Vetta 1983; Gentili 1988:89-103.

${ }^{22}$ N 1996a:217.
} 
Although the personification may remain anchored in a set time and place, realistically reenacted and represented as synchronically autonomous within a past far removed from the present, the persona itself keeps coming alive in the here and now of performance. And each different performance may bring back to life a different-even if ever so slightly differentpersona. Yes, there may have been a real-life Alcaeus, and his real-life circumstances may indeed be a starting-point that generates a distinctive Alcaic $\{31 \mid 32\}$ tradition. But with each occasion in which Alcaeus becomes re-enacted in performance for "his" hetaireia at a symposium, he is moved one occasion farther away from the ostensibly prototypical occasion.

Rösler's real-life Alcaeus is of course no poet-at least, no professional poet. Yes, he is good at singing and songmaking, far better than most, and he sings the kinds of songs at symposia that his hetairoi will long remember, long after he is gone, certainly at least long enough until the time comes-let us say around the middle of the sixth century-when it becomes technologically possible to transcribe for posterity the songs of Alcaeus as memorialized by his hetairoi in an open-ended succession of sympotic occasions. So goes Rösler's construct, in its broadest outlines.

I can agree with most of this construct, except for Rösler's insistence on the nonprofessionalism of Alcaic songmaking. Granted, the ambience of the Alcaeus persona seems distinctly nonprofessional, securely grounded as he is within the represented environment of his hetaireia. Granted, too, the re-enacted Alcaeus in the transmission of Alcaeus' songs by hetairoi could surely be a hetairos himself, that is, a member of the "group" writ large. But there are still questions: who is to say that the re-enacted Alcaeus has to be an amateur? Could he not be a professional performer?

Before any answer can be formulated, we must confront the distinction between group and audience. This distinction can be correlated in part with nonprofessionalism and 
professionalism in songmaking traditions. For a specific example, we may turn to comparative ethnographic evidence. Let us consider the living oral epic traditions in today's India, concentrating on the circumstances of performance and of performer-audience interaction. In the Indian traditions, the notion of audience is clearly more appropriate in the case of professional singers' performances, whereas some more neutral term like group suits the sort of situation where "nonprofessional general caste groups sing for the group itself." ${ }^{23}$ In general, the term group suits the situations of ritual. Such group performance, where the general caste-group participates in the "nonprofessional" performing of epic, provides the broadest possible category for the very concept of performer. And yet, even such group performance has its own built-in hierarchy: there has to be a leader, who generally has had more background in performance than the others, often including the mastery of an accompanying musical instrument. ${ }^{24}$

I posit a further distinction:

Whereas a performer performs for an audience, a group can perform together for each other. Group performance is possible even if some members $\{32 \mid 33\}$ take on far more important roles than others, to the extent that an outsider may not even be able to distinguish a group from an audience. So long as the mentality of group performance is there, everyone who is present at a mimesis becomes part of it. ${ }^{25}$

When I say "group" here, I have in mind not only the dramatic setting of, say, the hetaireia addressed by Alcaeus at one time and one place but also the historical setting of the symposium, with all its countless variations in time and place, where the spirit of hetaireia

\footnotetext{
${ }^{23}$ Kothari 1989:103.

${ }^{24}$ Ibid.

${ }^{25}$ N 1996a:83.
} 
provides the context for countless re-enactments of Alcaeus' words in song. ${ }^{26}$ Thus the dramatic setting of Alcaeus' words addressed to his hetairoi, which was primarily the symposium according to Rösler, can be perpetuated in a historical setting that is primarily this same medium, the symposium.

In my previous work, I have argued extensively that the performance traditions of melic compositions that were attributed to the likes of Alcaeus and Sappho-as also of non-melic compositions attributed to the likes of Theognis and Archilochus-were perpetuated by the medium of the symposium, in all its varieties.$^{27}$ The figure of Theognis, for example, "speaks less as a generalized choral personality and more as a specialized sympotic personality" (cf. especially Theognis 239-243); ${ }^{28}$ even the verses of Archilochus, at least those composed in elegiac couplets, were suited for performance at symposia. ${ }^{29}$ Also, we know that Sappho's songs were performed at symposia. In one source, Solon of Athens is pictured as becoming enraptured by a song of Sappho as sung by his own nephew at a symposium (Aelian via Stobaeus 3.29.58)..$^{30}\{33 \mid 34\}$

\footnotetext{
${ }^{26} \mathrm{~N}$ p. 84.

${ }^{27}$ Ibid.; also N 1990a:15, 107, 109-110, 112, 113, 115, 340-342, 368+371, 375, 409, 435, 436, 437. Cf. Murray 1990:8. As in my previous work, I use "melic" and "non-melic" here to distinguish two kinds of "lyric": a fully melodic medium, as typical of the monodic songs of Sappho and Alcaeus, and a reduced melodic medium, as typical of the iambic and elegiac poems of Archilochus and Theognis.

${ }^{28} \mathrm{~N}$ 1990a:368n159. See also Bowie 1986. Perhaps it is not necessary to postulate, as does Bowie on p. 14, that the elegiac verses of a figure like Theognis must have been accompanied by an aulós. I argue at N pp. 25-26 that such accompaniment may have been optional but not obligatory.

${ }^{29}$ Bowie pp. 16-18, especially with reference to Archilochus F 4 (also F 2).

${ }^{30} \mathrm{Cf}$. Herington 1985:35. For more on the singing of Sappho's songs at symposia, see Plutarch Sympotic Questions

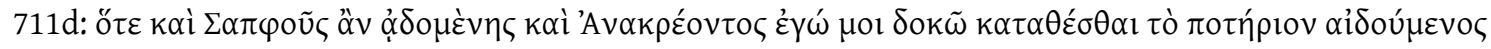
'whenever Sappho is being sung, and Anacreon, I think of putting down the drinking cup in awe'; also 622c:

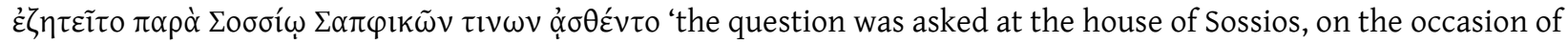
the singing of some Sapphic songs'; cf. Rösler 1980:101). Also Aulus Gellius Noctes Atticae 19.9 (mention of Anacreontic and Sapphic songs sung at a symposium by both boys and girls). I am grateful to Dimitrios Yatromanolakis for the last reference.
} 
We must also keep in mind the other central medium that perpetuated and to some degree transformed these performance traditions, that is, the State Theater of Athens. ${ }^{31}$ Further, we can connect these two media of the symposium and the theater with the institution of private schools, elitist training grounds that enhanced the artistic competitiveness and bravura inherent in the performance traditions perpetuated by the symposium and the theater. ${ }^{32}$ I will return to the topic of the symposium presently. For the moment, however, I stress simply the fundamental role of mimesis in all these traditions. And mimesis in its more archaic sense is predicated on the mentality of what we may call the group, as distinct from the audience. I repeat my general point: the term group suits the situations of ritual.

For purposes of comparison, the ongoing distinction between audience and group can be applied to the scenes of person-to-person or person-to-group interaction in Homeric narrative-not to mention the person-to-person format of the Hesiodic Works and Days. Let us consider as an example any given Homeric narration that pictures a woman singing a lament for the death of someone she loves, as when Andromache mourns the killing of her husband Hektor in Iliad XXIV 725-745: $:^{33}$

For those who are the characters inside the narrative, the woman is the performer of a song of lament, which is addressed directly or indirectly to the characters that hear her. For those who are the audience outside the narrative, a performer is re-enacting for his or her audience the woman who is singing the lament. Such re-enactment is a matter of mimesis. The point is, the person-toperson or person-to-group interaction in Homeric narrative mirrors the actual conventions of performer-audience interaction in the "real world" that frames

\footnotetext{
${ }^{31} \mathrm{~N} 1990$ a ch.13 in general.

${ }^{32}$ Ibid.; also N 1996a:85.

33 On which see Martin 1989:87.
} 
the performance of the narrative. It is as if the lamenting woman were addressing not only her group but also the audience that is listening to the performer as he re-enacts the woman. ${ }^{34}$

Such mirroring is pertinent to the "re-enacting I" of archaic Greek lyric, as in the songs of Alcaeus. I propose that the interaction of Alcaeus with his group on one level simply mirrors the performance of the Alcaeus-persona for an audience on another level. In historical times, we know that a professional rhapsōidos 'rhapsode' like Ion in Plato's Ion could be the performer, the re-enactor, of characters in the Homer poems-including of course such personae as the lamenting woman in the Iliad. Moreover, the rhapsode was the re-enactor $\{34 \mid 35\}$ of the persona who sang the Homeric poems, Homer himself. When the rhapsode says, "tell me, Muse," in performing Odyssey i 1, the "me" is notionally Homer. We also know that a professional rhapsode could re-enact the persona, say, of Archilochus (Plato Ion 531a, 532a; Clearchus F 92 Wehrli, via Athenaeus $620 \mathrm{c}) .{ }^{35}$ I return, then, to the question that I posed earlier: who is to say that the re-enacted Alcaeus could not be a professional performer as well? Granted, personae like Alcaeus could certainly be re-enacted by amateurs at symposia. But we know also that a professional kitharōidos 'citharode' could perform, before audiences, melic compositions akin to those of Alcaeus.

The earliest example of a kitharōidos 'citharode' is Terpander of Lesbos, a prototypical itinerant professional songmaker who was reportedly the first of all winners at the Spartan festival known as the Karneia (Hellanicus FGH 4 F 85 by way of Athenaeus 635 e). ${ }^{36}$ Tradition has it that the Feast of the Karneia was founded in the twenty-sixth Olympiad, that is, between 676 and 672 BCE (Athenaeus 635e-f). In other words the inception of the Karneia, an institution

\footnotetext{
${ }^{34}$ N 1996a:84, with reference to Martin 1989:87-88.

${ }^{35}$ Cf. N 1990a:25-26.

${ }^{36} \mathrm{Cf} . \mathrm{N}$ pp. 86-87, with further discussion.
} 
that was recognized by tradition as the oldest established festival of the Spartans, was reckoned on the basis of Terpander's victory in a contest of singing to the accompaniment of the lyre (Athenaeus 635ef). That Terpander was eventually thought to be a solo singer is clear from his being regularly designated as a kitharōidos ("Plutarch" On Music 1132d, 1133b-d). ${ }^{37}$ In Herodotus 1.23, the professional singer Arion, also from Lesbos (Methymna), is described as the premier kitharoidos of his time, in the era of the tyrant Periandros of Corinth. ${ }^{38}$ There is also one Phrynis of Mytilene, who won first prize as a kitharōidos in a contest at the Panathenaia of 456 (or possibly 446) in Athens (scholia to Aristophanes Clouds 969). ${ }^{39}$ Finally, the epigraphical evidence shows that rhapsōidoi and kitharōidoi (also aulöidoi), performing in competition at festivals, were awarded comparable sums for their prizes: examples include IG $I^{2} 2311$, an inscription concerning prizes at the Panathenaia (first half of the fourth century BCE) and IG XII ix 189 (Eretria, ca. 340 BCE)..$^{40}$

In my previous work, I have argued in general that the interchangeability between choral and solo media of lyric "presupposes a solid education of nonprofessionals in the art of professionals known as kitharōidoi." ${ }^{\prime 1}$ For example, in Aristophanes' Clouds, it is made clear that the ability of a nonprofessional to sing at a symposium a solo rendition of a choral composition of, say, Simonides (1355-1356), ${ }^{42}$ while accompanying himself on the lyre, depends on a $\{35 \mid 36\}$ level of paideia 'education' (961) that goes far beyond the training experience of the chorus and requires schooling by professionals in the art of singing on the lyre $(964,966) .{ }^{43}$ In studying the

\footnotetext{
${ }^{37}$ On the preeminence of kitharôidoi from Lesbos, see also Aristotle F 545 Rose and Hesychius s.v. $\mu \varepsilon \tau \grave{\alpha} \Lambda \varepsilon ́ \sigma \beta 1 o v$ ¿ڤóv.

${ }^{38}$ N 1990a:87.

${ }^{39} \mathrm{~N}$ p. 98 . On the date 446 see Davison 1968 [1958] 61-64.

${ }^{40}$ N p. 104.

${ }^{41}$ N p. 113.

${ }^{42}$ N p. 107.

${ }^{43}$ N p. 97.
} 
earlier phases of archaic Greek monody, I have also argued for the specific pattern of an "eventual differentiation of a composer / performer into a mythical protocomposer on the one hand and a contemporary professional performer, the kitharōidos 'lyre singer' or auloidos 'reed singer' on the other." ${ }^{44}$

The explicit references in Aristophanes Clouds 961-989 to the professional teaching of boys in the performance of lyre singing hark back to the "good old days" of the generation that had fought at Marathon. Likewise in Pindar's idealized vision of nonprofessional monodic performance at the symposium in the good old days before the Muses turned professional, as it were (Isthmian 2.1-13), the songs being sung are called paideioi humnoi 'songs of boyhood' (Isthmian 2.3), an expression that suggests paideia and paiderastia simultaneously. ${ }^{45}$ As I have argued in my earlier work, the references in Aristophanes to the old-fashioned schooling of nonprofessionals by professionals in the art of singing at symposia help put the notional spontaneity of the monodic moment into perspective. I sum it up this way:

The most we can say for nonprofessionalism in archaic Greek songmaking is that the monodic medium, in contexts like the symposium, may at least allow for composition on a nonprofessional as well as professional level, whereas the choral medium of a figure like Pindar, according to his own words, has become restricted to the composition of professionals. Also, the monodic medium allows for performance on a nonprofessional as well as professional level, whereas the choral medium, as performed by the khoros 'chorus', is restricted to performance by nonprofessionals. Moreover, even choral compositions can be re-performed by nonprofessionals at symposia as solo pieces, but then these

\footnotetext{
${ }^{44}$ N p. 340.

${ }^{45} \mathrm{~N}$ p. 342, where I explore briefly the archaic ideology of a cause-and-effect interchangeability between paideia and paiderastia. Cf. Kurke 1991:252; also Bremmer 1990.
} 
nonprofessionals are expected to accompany themselves on the lyre, and that in turn requires professional education in the specialized art of kitharōidia 'lyre singing'. In fact such solo performance was the ultimate sign of education, of direct access to the old traditions of song. ${ }^{46}$

Such a state of affairs, apparently typical of Athens in the era of Aristophanes, is far removed from the glory days of this art of solo self-accompanied $\{36 \mid 37\}$ singing at the symposiumthose days when the paideioi humnoi 'songs of boyhood', as the words of Pindar claim, were still an amateur affair (Isthmian 2.3). The switch from nonprofessional to professional standards in this art corresponds, I suggest, to a switch from group-mentality to audience-mentality; it also corresponds to what I have been calling the destabilization of mimesis. By the time of Aristophanes, the nonprofessionalism of solo self-accompanied singing at a symposium has become a veneer for the professionalism inherent in a private educational system that sustained the ideology of the amateur:

In a word the symposium was a last stand for nonprofessional performance of both monodic and choral compositions. Still the choral medium was already professionalized in the dimension of composition, and the monodic, in the dimension of transmission through such specialized skills as kitharoidia 'lyre singing, ${ }^{47}$

With this background, I return to the argument that the performance traditions of Alcaeus were perpetuated by the medium of the symposium, in all its varieties. While I continue to accept this argument, I must now add that the key to the actual transmission of this art of nonprofessional singing must have been the tradition of the professional kitharoidos, which can

\footnotetext{
${ }^{46} \mathrm{~N}$ p. 342.

${ }^{47}$ Ibid.
} 
be traced from the earliest archaic period of Lesbos, the era of Terpander, all the way to the Classical period of Athens and beyond, an era where the culmination of paideia found its ultimate expression in the self-accompanied performance of "Classics" like Alcaeus at a symposium.

A striking example is the reference in Aristophanes F $235 \mathrm{Kassel} /$ Austin to the singing of a

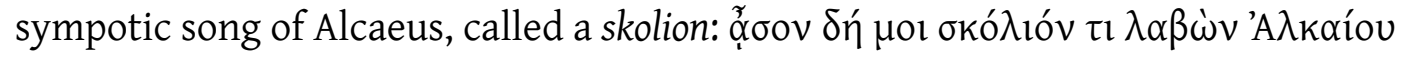

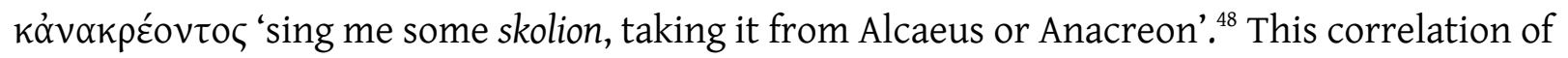
Alcaeus with Anacreon as masters of sympotic songmaking is particularly valuable in light of the explicit identification of Anacreon with the institution of the symposium: in Herodotus 3.121 , this poet is pictured as actually participating in a $\{37 \mid 38\}$ symposium attended by his

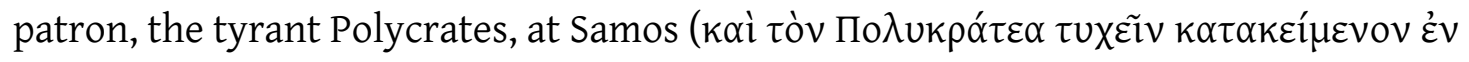

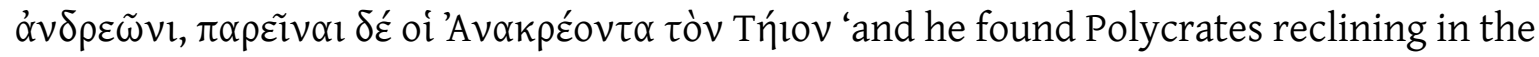
men's quarters, in the company of Anacreon of Teos')..$^{49}$

How, then, are we to imagine the performance of such a sympotic song of Alcaeus, known as a skolion in the era of Aristophanes, on the specific occasion of any symposium held at Athens in those later times? In fact, we see the attestation of just such an Attic skolion in the anonymous song PMG 891:

\footnotetext{
${ }^{48}$ The word skolion, as used in the time of Aristophanes, is a distinctly sympotic term. It was an appropriate general designation for the performance, self-accompanied on the lyre, of compositions by the great lyric masters (Harvey 1955:162-163, following Reitzenstein 1893; N 1990a:106-107). To engage in these performances was an old-fashioned convention at symposia, as we can see from such references as Aristophanes Clouds 1355-1356, the scholia to Aristophanes Wasps 1222, and Eupolis F 139 Kock (by way of Athenaeus 638e). According to "Plutarch" On Music 1140f, Pindar attributed the "invention" of the skolion to Terpander, who is also the traditional "inventor" of the system of melodies used in kitharoidia (On Music 1132d). I should add that Aristotle refers to Alcaeus F 348, which he also cites, as a skolion (Politics 1285a35 and following).

${ }^{49}$ Commentary by Urios-Aparisi 1993:54 on the explicitly sympotic features of the description given by Herodotus.
} 


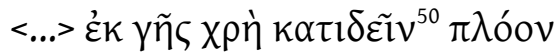

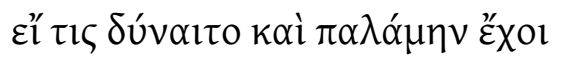

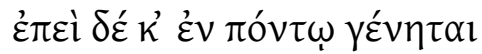

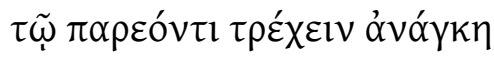

One must look down from land toward the direction of sailing,

if one can and has the power;

for once one is on the high sea,

one must speed along with whatever one gets.

This song, along with a string of other short songs, is quoted by Athenaeus (695a), who describes them all as skolia (694c). It matches in its wording one of the stanzas of a song of Alcaeus, F $249.6-9 \mathrm{~V}:^{51}$

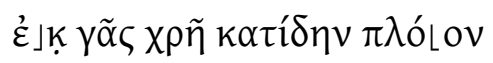

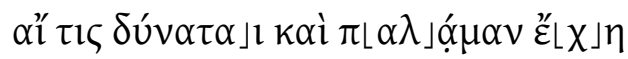

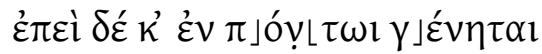

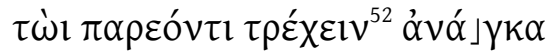

Our anonymous Attic skolion and the other Attic skolia quoted by Athenaeus $694 \mathrm{c}$ and following are to be dated to the late sixth and early fifth centuries $B C E .{ }^{53}$ The problem is, the text of our Attic skolion, PMG 891, is for the most part written in Attic dialect, while the papyrus text of the Alcaeus song containing the corresponding strophe, F 249.6-9, is for the most part written in Lesbian Aeolic. $\{38 \mid 39\}$

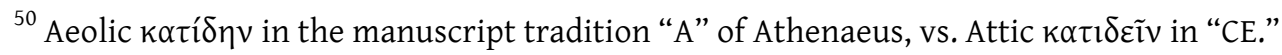

${ }^{51}$ Cf. Nicosia 1976:73-74. From here on, I will leave off the editor's tag V (Voigt) when I cite fragments of Alcaeus and Sappho.

${ }^{52}$ The papyrus gives a non-Aeolic spelling here, instead of the expected $\tau \rho \varepsilon ́ \chi \eta \nu$.

${ }^{53}$ Rösler 1980:96-97.
} 
There is no need, Rösler argues, to emend away the Atticized veneer of the Attic skolion as transmitted in Athenaeus for the purpose of matching the Aeolic dialectal veneer of the corresponding stanza in the song as reflected in the papyrus transmission of Alcaeus. ${ }^{54} \mathrm{We}$ need not expect Athenian symposiasts in the late sixth and early fifth century BCE, the apparent date of the Attic skolion PMG 891, to perform a song of Alcaeus in echt Aeolic. It is more appropriate to ask how exactly the echt Aeolicisms of the Lesbian poetic tradition were transmitted in the first place.

To repeat Rösler's earlier point, there is no evidence that the songs of a figure like Alcaeus were already texts in the archaic period, at around $600 \mathrm{BCE}$. And yet, the textual transmission of Alcaeus-and of Sappho as well-reveals a wealth of concrete linguistic realities on the levels of dialect, prosody, and even orthography. ${ }^{55}$ This transmission was mediated by scholars of the Library at Alexandria in the Hellenistic period, and I infer from the surviving textual evidence of the Alexandrian editions of Alcaeus and Sappho that these versions reflected accurately, from the standpoint of historical linguistics, the authentic Dichtersprache of Lesbos. ${ }^{56}$ Still, I consider it a problem that the Alexandrian scholars seem not to have taken an active interest in the actual performance traditions of archaic Greek poetry-only in the textual traditions. ${ }^{57}$ Earlier scholars in Athens, however, including Aristotle himself, clearly did take such an interest in poetic performance.$^{58}$ It seems to me most likely that the initial impetus for

\footnotetext{
${ }^{54}$ Ibid.

${ }^{55}$ Pathfinding work by Risch 1946 on the dialect reflected by the textual transmission of Alcaeus.

${ }^{56}$ From the linguistic data ably assembled by Bowie 1981, especially pp. 49-56, I find it in fact impossible to conclude otherwise. I disagree, however, with Bowie's assumption that the Alexandrian textual traditions of Alcaeus and Sappho go all the way back to the archaic period (e.g. on p. 95, Bowie writes "Sappho, after all, wrote EYPEAN").

${ }^{57}$ N 1996a:130, 150.

${ }^{58}$ Ibid. Moreover, there is evidence for this kind of scholarly activity even before Aristotle. Isocrates, in the Panathenaicus or "Panathenaic" speech (issued in 339 BCE), refers negatively to some so-called "sophists in the Lyceum" who practice the art of the rhapsodes in that (1) they perform the poems of Homer, Hesiod, or others
} 
$\{39 \mid 40\}$ editing various non-Athenian songmaking traditions, including those of Alcaeus and Sappho, can be traced back to fourth-century Athens. In this period, I suggest, there were scholars who took an interest in producing texts that reflected accurately the dialectal distinctness of such non-Athenian traditions.

One such scholar emerges from the evidence of a text of Isocrates, Letter 8, To the Rulers of Mytilene (dated around $350 \mathrm{BCE}$ ). In this letter, Isocrates is pleading for the restoration from exile of Agenor of Mytilene in Lesbos, currently residing in Athens and serving as the "music teacher" of Isocrates' grandsons (paideuthentes ... ta peri tēn mousikēen, section 1). The father of

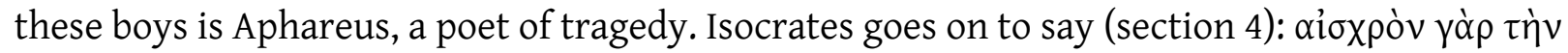

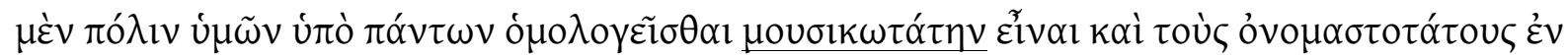

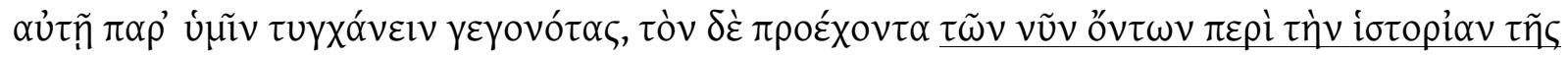

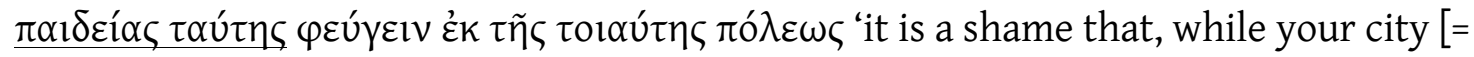
Mytilene] is acknowledged by all to be the most "musical" and the most famed figures in that

and (2) they are mnèmoneuentes 'mentioning', in a supposedly derivative way, the khariéstata or 'most elegant things' about these poems $(12.18-19,33)$. I suggest that this criterion of khariéstata or 'most elegant things', attributed to these "sophists in the Lyceum" who perform just like rhapsodes and who supposedly offer no critical judgment of their own about such poets, resorting instead to "what has previously been said by others," is a precursor of the criterion, as formulated by Aristarchus, that privileges those Homer editions that are supposedly khariésterai 'more elegant' or khariéstatai 'most elegant'; when Aristarchus had to choose among variant readings, he preferred whichever one was khariestáte 'most elegant' (N 1996a:116-124). I also draw attention to Isocrates' description of the "sophists in the Lyceum" as mnemoneuontes 'mentioning' received knowledge about poetry that they perform just like rhapsodes. The question arises: are they not only performing but also 'commenting' or 'making commentaries' on these poems by virtue of 'mentioning' received knowledge about them? We may compare the claim of Socrates, in Plato's Ion, that a rhapsode must be a hermèneus 'interpreter' of a poet like Homer, and that therefore he must surely know the poet's intention, or diánoia (531c). Again it seems that the rhapsode is expected to make a commentary on the poet he performs. Ion responds to Socrates by counter-

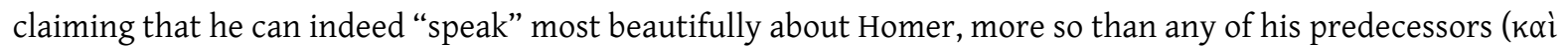

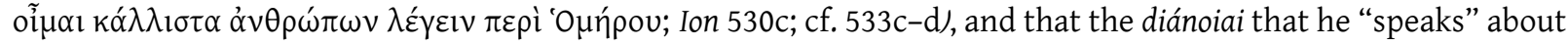
Homer are more beautiful than those spoken by any of his predecessors, such as Metrodorus of Lampsacus,

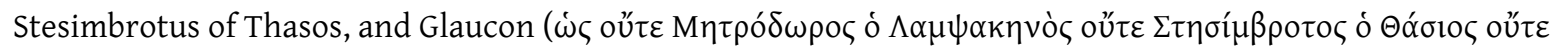

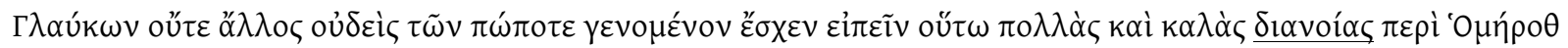

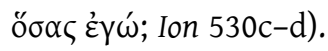


field [ $\dot{\varepsilon} \vee \alpha \dot{v} \tau \tilde{\eta}]$ happen to have been born in your city, yet he who is preeminent among those

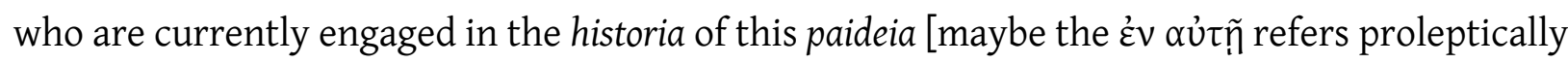
to this paideia ] is an exile from such a city, ${ }^{59}$

I infer from Isocrates' use of the word historia in this context that scholars in fourthcentury Athens were engaged in research on producing a dialectally accurate "script" for teaching the songs of Alcaeus and Sappho. ${ }^{60}$ I also infer that the word paideia refers to the practical activity of teaching youths how to perform these songs. Isocrates goes on to argue (section 9) that Agenor and his kin, if they were restored from exile, would not be offensive to

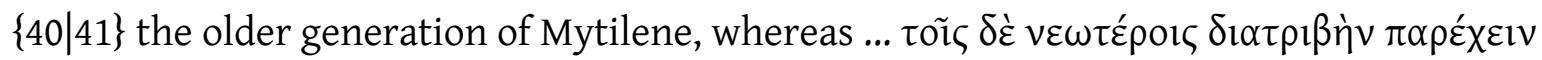

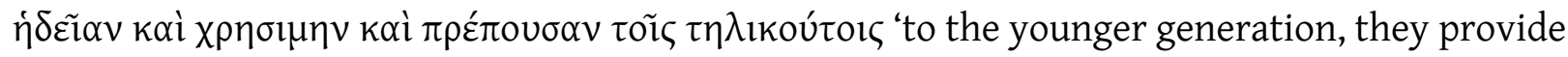
an activity that is pleasant, useful, and appropriate [to their age]'. Again I note the ideology of paideia.

How, then, are we to imagine such paideia in the specific context of mimesis in a symposium? I ask the question with reference not only to Alcaeus but also to all other "Classics" that were performed at symposia. As we will see, these "Classics" could include even such figures as Archilochus. ${ }^{61}$

A case in point is Alcaeus F 401B, by way of Strabo 13.1.38 C600, where the speaker announces the loss of his weapons in battle. The textual transmission of the brief passage is unfortunately garbled, but we can see from one clear stretch of wording that the enemies of the Mytilenaeans, the Athenians, have captured the speaker's weapons and dedicated them in

\footnotetext{
${ }^{59}$ N 1996a:192.

${ }^{60}$ On historia in the sense of research about poetry, cf. Hermesianax F 7.22. As Victor Bers points out to me, Isocrates' claim that Agenor was engaged in historia concerning the teaching of these songs implies that Agenor's experience goes beyond having learned them in school himself. I infer that his activities extended to research in the establishment of the text, including matters of dialect, meter, and the like.

${ }^{61}$ On the performance of Archilochus at symposia, cf. Rösler 1990:234, with reference to Archilochus F 93a-b, 94, 98-99.
} 


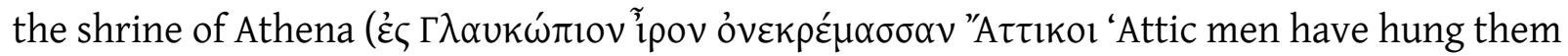
in the shrine of the Glaukopis'). This kind of theme is better known from another passage, Archilochus F 5, where the speaker announces that he has lost his shield to the enemy in battle and expresses no regrets, since at least he saved himself:

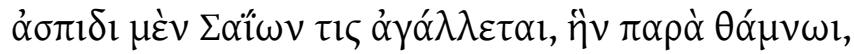

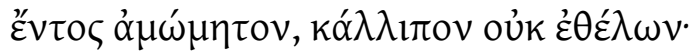

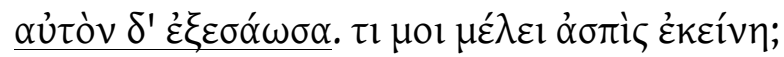

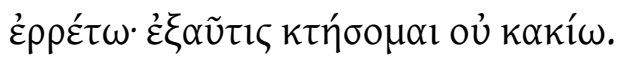

One of the Saïoi must be glorying in the shield that, in a thicket, - excellent weapon - I left behind, against my will.

But I saved myself. Why should I care about that shield?

Let it go to perdition! Next thing you know, I will own one no worse!

\section{Archilochus F 5 W}

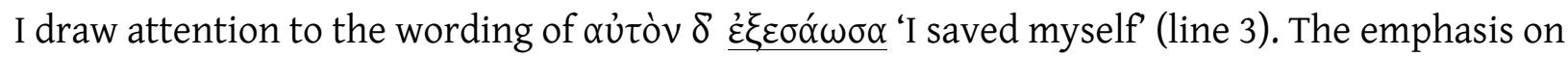
the warrior's saving himself, literally his self, at the expense of his shield is paralleled by the

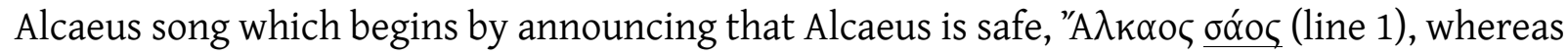
his weapons are in the hands of the enemy (line 2). What is striking about both the Archilochus and the Alcaeus passages is the mocking challenge to the warrior ethic of equating one's shield with one's identity, as most explicitly articulated in the song of Hybrias the Cretan, PMG 909:

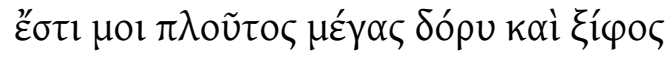

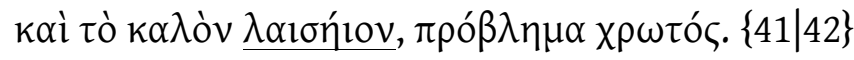

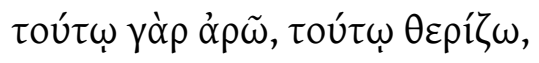

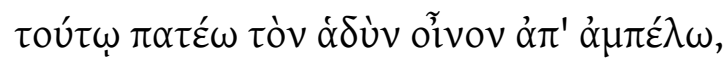




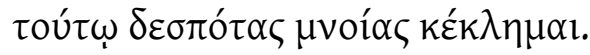

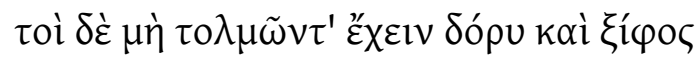

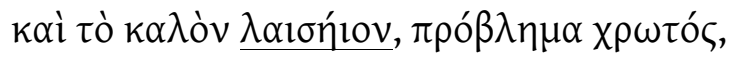

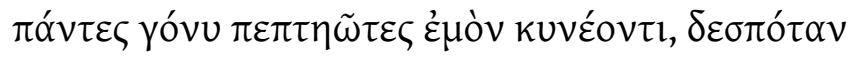

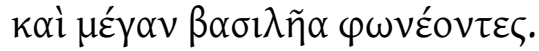

My great wealth is a spear and a sword

and a beautiful shaggy hide-shield [laisēion], an extension of the skin.

With this I plough, with this I reap,

with this I tread the sweet wine out of the vine.

With this I am acclaimed as master of serfs.

But those who dare not have a spear and a sword

and a beautiful shaggy hide-shield [laisēion], an extension of the skin,

all of them cower and kiss my knee. Master

and great king they call me.

Athenaeus, who quotes this song (695f-696a), identifies it as a skolion. Here the warrior's laisëion 'shaggy hide-shield' (a special type of hide-shield with the animal's hair left on the

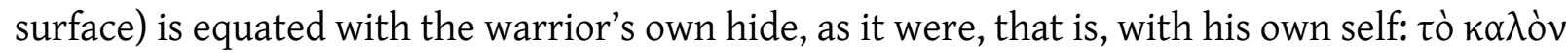

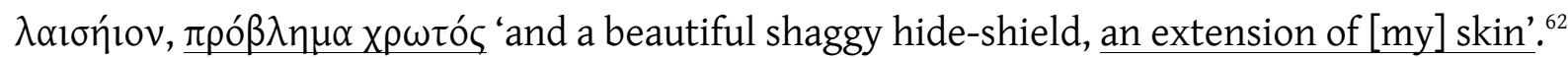
For further evidence on the equation of the concept of a hide-shield with the self, I compare the Homeric word sakos 'cowhide shield' and its cognate, Sanskrit tvác- 'hide', with another cognate, Hittite tweka-, which is used with the first-person possessive in autobiographical

\footnotetext{
${ }^{62}$ This passage was brought to my attention in a paper delivered 16 May 1993 by Andrew Ford on the occasion of a colloquium held at the University of Lille; the paper concerned the symposium as a medium for transmitting lyric traditions. At the same colloquium, Claude Cichy presented a paper arguing that Archilochus $\mathrm{F} 5$ challenges the ethic of the Achilles narrative in the Homeric Iliad.
} 
contexts to mean 'my self, myself, $I{ }^{3} \cdot{ }^{63}$ In the theme of the lost shield, then, what we see is the detachment of the warrior's ego from the weapon that conventionally identifies the warrior.

If indeed Alcaeus is primarily a sympotic figure, as conveyed in the varieties of ethos that are being acted out in the songs attributed to him, then it is all the more natural for any sympotic performer of Alcaeus to have a relatively strong sense of identification with him in performance. ${ }^{64}$ But there is also distancing, through the strong identification of $\{42 \mid 43\}$ Alcaeus with his own dramatized time and place. I merely note in passing the "situation ethics" of Alcaeus F 401B, dramatized as a message intended for his own hetairoi. We are told by Strabo 13.1.38 C600, who quotes F 401B, that these words about the loss of Alcaeus' shield are being spoken to some "herald" (kērux), who is being told to "announce" (angeilai ) them to Alcaeus' group back home. ${ }^{65}$ Herodotus $5.94-95$ says that Alcaeus "composed" these words "in a melic song" (en melei poiessas) and then "sent" (epitithei ) them to Mytilene, "announcing" (exangellomenos) his "misfortune" (pathos) to his hetairos, one Melanippos. Thus the melic song, recognized as such by Herodotus, "acts out" a dramatic situation with localized martial and civic undertones. It is as if the melic song were not the poetic production that it is but rather a historical moment when a warrior-citizen is making an announcement, by way of a herald, to his hetairos. If it had not been for that hetairos, how would the symposiasts of the here-and-now who are singing this song ever know that Alcaeus had once said such a thing? That is the premise, I suggest, of the mimesis. We recall Rösler's dictum, "ohne Hetairie, kein Lyriker Alkaios."

This kind of dramatized alienation, however, whether it be expressed in mocking or in serious tones, is not necessarily a declaration of the dramatized speaker's ultimate

\footnotetext{
${ }^{63}$ N 1990b:264-265. Mary Ebbott points out to me the relevance of Iliad 11.526-527: the Trojans recognize Ajax by recognizing his shield.

${ }^{64} \mathrm{~N} 1996 \mathrm{a}: 217$.

${ }^{65}$ On angelia 'announcement' as a programmatic aspect of song, see Nash 1990, especially with reference to the poetics of Pindar.
} 
independence from the group. As I have argued extensively elsewhere with specific reference to the elegiac poetry of Theognis, the poet's expressions of alienation from the group in the here and now become part of a larger plan, where dramatic confrontations lead ultimately to integration with the group in the fullness of time. ${ }^{66} \mathrm{~A}$ case in point is Theognis $19-24$, the extended passage that I have quoted above. There and elsewhere, the performance tradition that frames various dramatic scenes of immediate rejection or social failure, thus testing the solidarity of the group, is pervaded by various self-referential signs indicating ultimate acceptance or social success ${ }^{67}$ On the basis of this prophesied reception, the author lays claim to a timeless authority, which resists the necessity of changing just to please the audience of the here and now, who are described as the astoi 'townspeople' (Theognis 24). ${ }^{68}$

The reception of such songmaking is achieved through the authority and authenticity of mimesis:

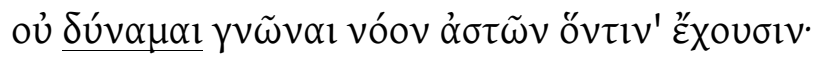

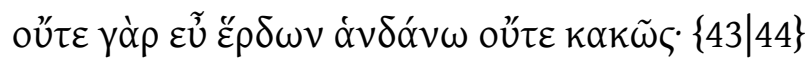

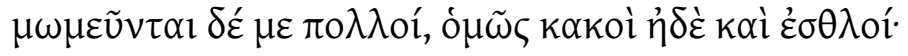

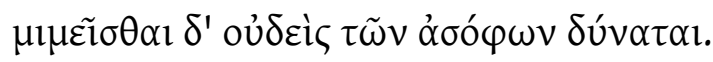

I am unable to decide what disposition it is that the townspeople [astoi] have towards me.

For I do not please [= verb handanein] them, either when I do for them things that are advantageous or when I do things that are disadvantageous. ${ }^{69}$ There are many who find blame with me, base and noble men alike.

\footnotetext{
${ }^{66} \mathrm{~N} 1985: 33-35,76$.

${ }^{67} \mathrm{~N}$ pp. 29-32.

${ }^{68}$ Ibid.

${ }^{69}$ The "doing," of course, may amount simply to the performative level of "saying" by way of poetry.
} 
But no one who is not skilled [sophos] can re-enact [mimeisthai] me.

Theognis $367-370$

Here we see the persona of Theognis declaring that only the one who is sophos, that is, 'skilled' in the decoding and encoding of poetry, can execute a mimesis of Theognis:

Here the notion of mimesis becomes an implicit promise that no change shall ever occur to accommodate the interests of any local audience in the here and now, that is, of the astoi 'townspeople'. The authorized re-performance of a composition, if it is a true re-enactment or mimesis, can guarantee the authenticity of the "original" composition. The author is saying about himself: "But no one who is not skilled [sophos] can re-enact my identity."70

By implication, only the pleasure of exact re-performance, ostensibly the ongoing achievement of mimesis, is truly lasting, while the pleasure elicited through changes in response to an immediate audience is ephemeral. ${ }^{71}$

With these adjustments, I can follow Rösler in arguing that there is no "fiction" per se on the occasion of, say, an interchange between Alcaeus and his comrades. Or for that matter between Archilochus and his comrades. I would add, though, that there is indeed reenactment. There are model situations to be acted out. There is, in a word, a ritual frame, a performative frame. And an ideal way to hear Alcaeus performed, even in the Classical era of Athens, is surely the symposium.

Even in the case of Archilochus, as I am about to argue, it seems that hearing his verses performed in the symposium may be conducive to an overall sense of social cohesion, whereas

\footnotetext{
${ }^{70} \mathrm{~N}$ 1996:223.

${ }^{71}$ Ibid.
} 
hearing these same verses performed by a rhapsoidos at a public concert may be less "safe," with implicit dangers of moral corrosion. ${ }^{72}$ I should note in advance that the same might $\{44 \mid 45\}$ perhaps be said about hearing a song of Alcaeus performed by a kitharōidos at a public concert. Still, the direct evidence at hand concerns the performance of compositions attributed to Archilochus.

The evidence comes from Aristotle. In the passage about to be quoted, he is saying that the paideia 'education' that a boy acquires by hearing (and, presumably, by learning to perform) songs in the symposium serves to immunize him against the potentially harmful effects of

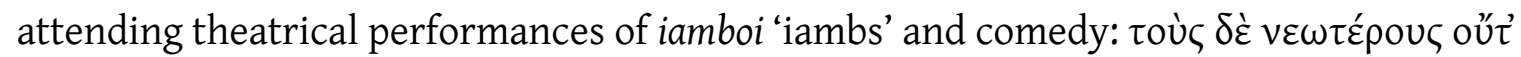

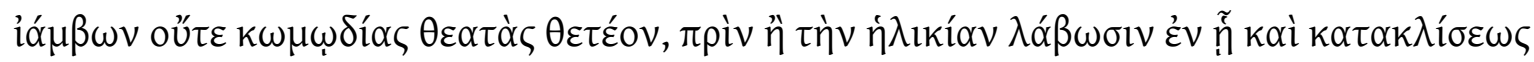

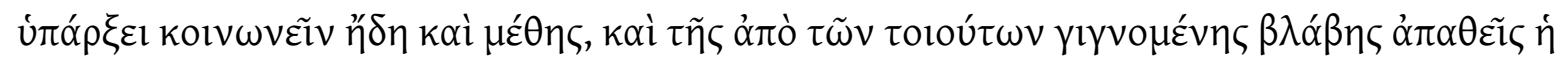

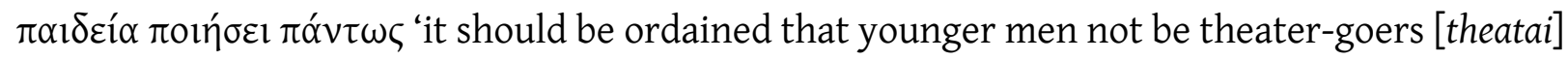
of iamboi or of comedy until they reach the age where they have the opportunity to participate in lying down together at table and getting intoxicated [that is, to participate in symposia], at which point their education [paideia] will make them altogether immune to the harmful effect of these things' (Politics 1336b20-22). ${ }^{73}$

By implication, the mimesis inherent in the performances of iamboi or of comedy in the theater concentrates on negative varieties of ethos. By contrast, I infer that "the paideia of mimesis in the symposium-even the cumulative ethos of the symposium-provides a proper balance for Hellenic youth in their educational experience of learning the variations of ethos." ${ }^{74}$ One critic has put it this way: "... if the hetaireia really was the successor to the old warrior clubs, we may expect that in some way it was also concerned with the education of the

\footnotetext{
${ }^{72}$ As I have already pointed out, the repertoire of the professional rhapsode could include Archilochus (Plato Ion 531a, 532a; Clearchus F 92 Wehrli, via Athenaeus 620c).

${ }^{73}$ Cf. Bremmer 1990:139 and Bartol 1992:66.

${ }^{74}$ N 1996a:218.
} 
young. We shall look therefore not so much for a strict ritual as for an attitude, a habitus, towards the young at the symposion which can be best explained as having developed from older, stricter customs." ${ }^{\text {"T }}$ The symposium, I conclude, provides a "safe" occasion for morally vulnerable youth to hear things that might be "unsafe" to hear in the theater. ${ }^{76}\{45 \mid 46\}$

When Aristotle pairs iamboi with comedy as typical of what is "unsafe" for under-age consumption in the theater, he is apparently thinking of Archilochus, the primary exponent of iamboi. When he argues that iamboi were a prototype of comedy (Poetics 1448b32-1449a6), ${ }^{77}$ he may well have Archilochus F 120 specifically in mind (1449a9ff). ${ }^{78}$ And yet, though Aristotle disapproves of theater for representing the negative morality of rogues or of roguish behavior in iamboi and comedy, it seems that he approves of the symposium as a context for performing this kind of poetry.

An example of such roguishness is Archilochus F 4.7-8, where the speaker says that "we" cannot endure guard-duty without drinking wine:

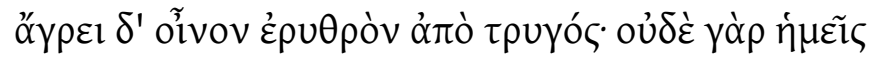
$\vee \eta \varphi \varepsilon ́ \mu \varepsilon v \dot{\varepsilon} \vee \varphi v \lambda \alpha \kappa \tilde{\eta} \iota \tau \tilde{\eta} 1 \delta \varepsilon \delta \cup v \eta \sigma o ́ \mu \varepsilon \theta \alpha$.

Take the red wine from the very lees! For we will not be able to stay sober during this watch.

\footnotetext{
${ }^{75}$ Bremmer 1990:136.

${ }^{76} \mathrm{~N}$ 1996a:218. My interpretation of the Aristotle passage depends on the premise that the paideia here refers to whatever the boy learns-by way of songs and the erotic sensibilities conveyed in the songs-as preparation for participation in the symposium. See N 1996a:163n37, following the analysis by Calame 1989 of a red-figure painting by Douris on a drinking-cup produced between 490 and 480 BCE (ARV ${ }^{2} 431,48$ and 1653; CVA II pp. 29-30, with plates 77 and 78): the painting illustrates the sympotic education of boys in the performance of song and musical accompaniment. As Calame argues (p. 53), the songmaking apprenticeship of the boys, with distinct implications of homoerotic undertones, is being represented as a prerequisite for the integration of adolescents into the symposia of adult citizens, which is the context for which the drinking-cup of Douris is destined.

${ }^{77} \mathrm{~N}$ 1979:253.

${ }^{78}$ N 1990a:394-395.
} 
The question is: are we witnessing here a real situation? One critic offers this answer: "I think it far more probable that Archilochus is evoking a situation with which his audience was all too familiar but which they could thank the gods was not their actual situation while they sang." My own answer, with a different point of emphasis, is this:

The negative morality that is being represented in this composition is being framed by the positive morality of the symposium as the setting of the representation. If I understand Aristotle correctly, the same representation in a setting that is different from the symposium, such as the theater, would make it easier for impressionable youth to become vulnerable to the negative morality that is being dramatized. In other words, Aristotle seems to be saying that the symposium provides a proper frame for moral discrimination, whereas the theater is more hazardous. ${ }^{80}$

Returning to the songs of Alcaeus, grounded as they are in the institution of the symposium, I conclude that all questions of genre and occasion must be answered in terms of this institution's own traditions of performance. In these terms, it is not enough to make distinctions between, say, a "real" and a "fictional" occasion, because the reality that is being represented in a given song is itself generic, applicable beyond any referent within that song. It is not enough, further, to consider only those occasions that we attribute to $\{46 \mid 47\}$ Alcaeus himself, on the basis of whatever it is that the "I" of Alcaeus says in his songs. The mimesis of Alcaic songmaking may extend the "I," for example, to characters other than that of Alcaeus. A case in point is Alcaeus F 10, where the dramatized character who is speaking is clearly female (cf. Anacreon PMG 385). We must also consider in general the occasions in which the re-

\footnotetext{
${ }^{79}$ Bowie 1986:16.

${ }^{80}$ N 1996a:219.
} 
enacted "I" of Alcaeus continues to speak-the occasions of real symposia. The remote occasions of Alcaeus keep getting re-enacted, keep coming back to life, in the immediate occasions of the symposium.

In any song of Alcaeus, whatever anyone says about anything-including whatever Alcaeus may say about himself-is ultimately a matter of mimesis. Mimesis may easily convey a represented reality to its own audience, but not so easily to readers like us, removed as we are from the context of performance. The difficulties can be illustrated with one particular expert's hesitations in interpreting Alcaeus F 6, a song that describes a storm at sea. This expert, Denys Page, begins by interpreting the storm as follows: "Alcaeus recreates it as if it were yet to be suffered." ${ }^{81}$ Page then proceeds to reject this interpretation: "To define a procedure so futile, and so discordant with the practice of ancient poets at any period, is alone enough to condemn it beyond belief." ${ }^{82}$ Page has been criticized for his judgment: "what he ignores is the dramatic element in non-dramatic poetry." ${ }^{" 83}$ I agree in part with this criticism, though I disagree with the idea that Alcaic poetry is "non-dramatic." Any song, I suggest, is dramatic to the extent that it is mimetic. ${ }^{84}$

For us it may seem as if mimesis were merely an acting-out. For an audience that accepts mimesis as re-enactment, however, whatever occasion is re-enacted in the performance of a song must be real or felt to be real, and the reality becomes reinforced by the rules that make it possible to re-create that given occasion by way of performance. These rules, I suggest, are the rules of genre.

\footnotetext{
${ }^{81}$ Page 1955:185.

${ }^{82}$ Ibid.

${ }^{83}$ Bowie 1986:17.

${ }^{84}$ N 1996a:85n77.
} 
To be sure, such rules of genre may be transgressed. But it is not enough to say that poets follow-and transgress-the rules of the genre. We must add that performers of song followand transgress-the rules of the occasion.

What, then, is a genre in Alcaeus? In public recitals as performed by kitharoidoi, a given genre of Alcaeus may be seen as a set of compositional rules creating a given occasion for the Alcaeus persona himself, in his historicized setting. In symposia, the same genre may become, more specifically, a set $\{47 \mid 48\}$ of compositional rules creating an actual sympotic occasion as celebrated by the Alcaeus persona. In this case, there is no audience per se, just a group of notional hetairoi. In both cases, however, the fundamental process of re-enactment, representation, is the same. And so long as there remains an occasion to be presented or represented in song, there must be a set of rules that singers may use in order to make this presentation or representation possible. These rules are a matter of genre. But the point is, they are the singers' rules, not necessarily the singers' real-life experiences.

The blues singer Rubin Lacy, recalling that he usually felt good when we was singing or composing the blues, was quoted as saying:

I've sung 'em on many a day and never thought I had 'em. What did I want to have the blues for, when I had everything I wanted, all the liquor, all the money I needed, and more gals than I needed? What did I need with the blues? I was playin' 'em because everybody loved to hear me play 'em and I loved to play 'em. I could play'em, yeah. ${ }^{85}$

According to this blues singer, then, the song does not necessarily express the real situation of the singer. You don't have to have the blues to sing the blues. This is not to deny the immanent sadness of the blues: it is only to say that the sadness of a song does not necessarily come from

\footnotetext{
${ }^{85}$ Quoted in Evans 1982:112. Thanks to Adam Holland.
} 
the sadness of the singer. You do not have to have the blues to sing the blues. So also with the sympotic singer: you do not have to lose your shield to sing about losing your shield.

\section{Bibliography}

Austin, J. L. 1962. How to Do Things with Words. Oxford.

Bacon, H. H. 1994/5. “The Chorus in Greek Life and Drama." Arion 3.2:6-24.

Bakhtin, M. M. [1981]. "Epic and Novel: Toward a Methodology for the Study of the Novel." In The Dialogic Imagination: Four Essays by M. M. Bakhtin (ed. M. Holquist, tr. C. Emerson and M. Holquist) 3-40. Austin.

Bartol, K. 1992. "Where Was Iambic Poetry Performed? Some Evidence from the Fourth Century BCE." Classical Quarterly 42:65-71.

Batchelder, A. G. 1994. The Seal of Orestes: Self-Reference and Authority in Sophocles' "Electra." Lanham, Maryland.

Bauman, R. 1977. Verbal Art as Performance. Rowley, Mass.

Bauman, R. 1977. Verbal Art as Performance.Prospect Heights, Illinois.

Ben-Amos, D. 1976. “Analytical Categories and Ethnic Genres.” Folklore Genres (ed. D. Ben-Amos) 215-242. Austin.

Ben-Amos, D. 1976. “Analytical Categories and Ethnic Genres.” Folklore Genres (ed. D. Ben-Amos) 215-242. Austin.

Blackburn, S. H., Claus, P. J., Flueckiger, J. B., and Wadley, S. S. eds. (1989) Oral Epics in India. Berkeley and Los Angeles. Abbreviated here as OEI.

Bowie, A. M. 1981. The Poetic Dialect of Sappho and Alcaeus. New York. 
Bowie, E. L. 1986. “Early Greek Elegy, Symposium and Public Festival.” Journal of Hellenic Studies 106:13-35.

Bremmer, J. N. 1990. “Adolescents, Symposion, and Pederasty.” Murray 1990:135-148.

Bundy, E. L. 1986. Studia Pindarica. Berkeley and Los Angeles. First published in 1962 as vol. 18 nos. 1 and 2 of the University of California Publications in Classical Philology.

Burkert, W. 1987. “The Making of Homer in the Sixth Century BCE: Rhapsodes versus Stesichorus," Papers on the Amasis Painter and His World (ed. M. True, C. Hudson, A. P. A. Belloli, B. Gilman, and others) 43-62. Malibu.

Burnett, A. P. 1989. “Performing Pindar's Odes.” Classical Philology 84:283-293.

Calame, C. 1974. "Réflexions sur les genres littéraires en Grèce archaïque.” Quaderni Urbinati di Cultura Classica 17:113-123.

Calame, C. 1977. Les choeurs de jeunes filles en Grèce archaïque I: Morphologie, fonction religieuse et sociale. II: Alcman. Rome.

Calame, C. 1989. “Apprendre à boire, apprendre à chanter: L'inférence énonciative dans une image grecque." La part de l'oeil 5:45-53.

Calame, C. 1994/5. "From Choral Poetry to Tragic Stasimon: The Enactment of Women's Song." Arion 3.2:136-154.

Carey, C. 1989. “The Performance of the Victory Ode.” American Journal of Philology 110:545-565.

Carey, C. 1991. "The Victory Ode in Performance: The Case for the Chorus.” Classical Philology 86:192-200.

Chantraine, P. 1968, 1970, 1975, 1977, 1980. Dictionnaire étymologique de la langue grecque I, II, III, IV-1, IV-2. Paris. Abbreviated as DELG. 
Clay, D. (1991) “Alcman’s Partheneion,” Quaderni Urbinati di Cultura Classica 39:47-67.

Croce, B. 1902. Estetica. 2nd ed. Bari.

Davison, J. A. 1958. “Notes on the Panathenaia." Journal of Hellenic Studies 78:23-41 = 1968:28-69.

Davison, J. A. 1968. From Archilochus to Pindar: Papers on Greek Literature of the Archaic Period. London.

Day, J. W. 1989. "Rituals in Stone: Early Greek Grave Epigrams and Monuments." Journal of Hellenic Studies 109: 16-28.

Edwards, V., and Sienkewicz, T. J. 1990. Oral Cultures Past and Present: Rappin' and Homer. Oxford.

Evans, D. 1982. Big Road Blues: Tradition and Creativity in the Folk Blues. Berkeley and Los Angeles.

Figueira, T. J., and Nagy, G., eds. 1985. Theognis of Megara: Poetry and the Polis. Baltimore.

Finnegan, R. 1970. Oral Literature in Africa. Oxford.

Flueckiger, J. B. 1989. “Caste and Regional Variants in an Oral Epic Tradition.” OEI 33-54.

Flueckiger, J. B. 1996. Gender and Genre in the Folklore of Middle India. Ithaca.

Flueckiger, J.B., and Sears, L.J., eds. 1991. Boundaries of the Text: Epic Performances in South and Southeast Asia. Ann Arbor.

Foley, J. M. 1985. Oral-Formulaic Theory and Research: An Introduction and Annotated Bibliography. New York.

Ford, A. L. 1985. "The Seal of Theognis: The Politics of Authorship in Archaic Greece." Figueira and Nagy 1985:82-95.

Gadamer, H.-G. 1975. Truth and Method. New York. 
Gentili, B. 1988. Poetry and its Public in Ancient Greece. Translated from the Italian by A. T. Cole. Baltimore.

Goldhill, S. 1991. The Poet's Voice: Essays on Poetics and Greek Literature. Cambridge.

Hainsworth, J. B. 1991. The Idea of Epic. Berkeley and Los Angeles.

Harvey, A. E. 1955. “The Classification of Greek Lyric Poetry.” Classical Quarterly 5:157-175.

Heath, M. 1988. "Receiving the kōmos: The Context and Performance of Epinician." American Journal of Philology 109:1-11.

Heath, M., and Lefkowitz, M. 1991. "Epinician Performance: A Response to Burnett and Carey." Classical Philology 86:173-191.

Henrichs, A. 1994/5. “Why should I dance?: Choral Self-Referentiality in Greek Tragedy.” Arion 3.2:56-111.

Herington, J. 1985. Poetry into Drama: Early Tragedy and the Greek Poetic Tradition. Berkeley and Los Angeles.

Jensen, M. Skafte 1980. The Homeric Question and the Oral-Formulaic Theory. Copenhagen.

Koller, H. 1954. Die Mimesis in der Antike. Bern.

Koller, H. 1972. “Epos.” Glotta 50:16-24.

Kothari, K. 1989. "Performers, Gods, and Heroes in the Oral Epics of Rajasthan." Oral Epics in India (ed. S. H. Blackburn, P. J. Claus, J. B. Flueckiger, and S. S. Wadley) 102-117. Berkeley and Los Angeles.

Kurke, L. 1991. The Traffic in Praise: Pindar and the Poetics of Social Economy. Ithaca.

Larson, J. 1995. Greek Heroine Cults. Madison 
Lefkowitz, M. 1988. “Who Sang Pindar's Victory Odes?” American Journal of Philology 109:1-11. Revised and reprinted in Lefkowitz 1991:191-201.

Lefkowitz, M. 1991. First Person Fictions: Pindar's Poetic “I.” Oxford.

Loraux, N. 1990. Les mères en deuil. Paris.

Lord, A. B. 1960. The Singer of Tales. Cambridge, Massachusetts.

Lord, A. B. 1991. Epic Singers and Oral Tradition. Ithaca.

Lord, A. B. 1995. The Singer Resumes the Tale (ed. M. L. Lord). Ithaca.

Martin, R. P. 1989. The Language of Heroes: Speech and Performance in the Iliad. Ithaca.

Morgan, K. A. 1993. "Pindar the Professional and the Rhetoric of the kōmos." Classical Philology 88:1-15.

Murray, O. 1983. "The Greek Symposion in History.” Tria Corda: Scritti in onore di Arnaldo Momigliano (ed. E. Gabba) 257-272. Como.

Murray, O. 1990. “The Affair of the Mysteries: Democracy and the Drinking Group." Sympotica: A Symposium on the Symposium (ed. O. Murray) 149-161. Oxford.

Murray, O. ed. 1990. Sympotica: A Symposium on the Symposium. Oxford. Note especially the introduction by Murray, "Sympotic History," pp. 3-13.

$\mathrm{N}=$ Nagy, $\mathrm{G}$.

N 1979. The Best of the Achaeans: Concepts of the Hero in Archaic Greek Poetry. Baltimore. 2nd ed., with new introduction, 1999.

N 1985. "Theognis and Megara: A Poet's Vision of His City.” Theognis of Megara: Poetry and the Polis (ed. T. J. Figueira and G. Nagy) 22-81. Baltimore. 
N 1990a. Pindar's Homer: The Lyric Possession of an Epic Past. Baltimore. 1994 paperback version, with corrections.

N 1990b. Greek Mythology and Poetics. Ithaca. 1992 paperback version, with corrections.

N 1993. “Alcaeus in Sacred Space." Tradizione e innovazione nella cultura greca da Omero all' età ellenistica: Scritti in onore di Bruno Gentili vol. 1 (ed. R. Pretagostini) 221-225. Rome.

N 1994. “Copies and Models in Horace Odes 4.1 and 4.2." Classical World 87:415-426.

N 1994/5a. "Transformations of Choral Lyric Traditions in the Context of Athenian State Theater," Arion 3.2:41-55.

N 1994/5b. “Genre and Occasion.” MHTIC 9/10.11-25.

N 1995. "Le rossignol d'Homère et la poétique de la mouvance dans l'art d'un troubadour." L'inactuel 4:37-63.

N 1996a. Poetry as Performance: Homer and Beyond. Cambridge.

N 1996b. Homeric Questions. Austin.

N 1999. "Epic as Genre." Epic Traditions in the Contemporary World: The Poetics of Community, edited by M. Beissinger, J. Tylus, and S. Wofford, 21-32. Berkeley and Los Angeles.

Nash, L. L. 1990. The aggelia in Pindar. New York.

Nehamas, A. 1982. "Plato on Imitation and Poetry in Republic 10." In Plato on Beauty, Wisdom, and the Arts, edited by J. M. C. Moravcsik and P. Temko, 47-78. Totowa, N.J.

Nicosia, S. 1976. La tradizione dei poeti di Lesbo. Rome.

Okpewho, I. 1979. The Epic in Africa: Toward a Poetics of the Oral Performance. New York.

Page, D. L. 1955. Sappho and Alcaeus: An Introduction to the Study of Ancient Lesbian Poetry. Oxford. 
Parry, M. 1971. The Making of Homeric Verse: The Collected Papers of Milman Parry, edited by A. Parry. Oxford.

Patton, K. C. 1992. When the High Gods Pour Out Wine: A Paradox of Ancient Greek Iconography in Comparative Context. Ph.D. dissertation, Harvard University.

Reichl, K. 1992. Turkic Oral Epic Poetry: Traditions, Forms, Poetic Structure. New York.

Reitzenstein, R. 1893. Epigramm und Skolion: Ein Beitrag zur Geschichte der alexandrinischen Dichtung. Giessen.

Risch, E. 1946. "Sprachliche Bemerkungen zu Alkaios.” Museum Helveticum 3:253-256. Reprinted in Risch 1981:290-293.

Risch, E. 1981. Kleine Schriften, edited by A. Etter and M. Looser. Berlin.

Rösler, W. 1980. Dichter und Gruppe: Eine Untersuchung zu den Bedingungen und zur historischen Funktion früher Lyrik am Beispiel Alkaios. Munich.

Rösler, W. 1985. “Persona reale o persona poetica? L'interpretazione dell 'io' nella lirica greca arcaica." Quaderni Urbinati di Cultura Classica 19:131-144.

Rösler, W. 1990. “Mnemosyne in the Symposion.” Murray 1990:230-237.

Rossi, L. E. 1971. “I generi letterari e le loro leggi scritte e non scritte nelle letterature classiche." Bulletin of the Institute of Classical Studies 18:69-94.

Sandys, J., tr. 1919. The Odes of Pindar. London / Cambridge, Mass.

Schein, S. L. 1987. “Unity and Meaning in Pindar's Sixth Pythian Ode.” MHTIL: Revue d'Anthropologie du Monde Grec Ancien 2:235-247.

Schmitt-Pantel, P. 1990. “Sacrificial Meal and Symposion.” Murray 1990:14-33. 
Slatkin, L. 1987. "Genre and Generation in the Odyssey," MHTIL: Revue d'anthropologie du monde grec ancien 2:259-268.

Smith, P. 1974. “Des genres et des hommes,” Poétique 19:294-312.

Svenbro, J. 1984. "La découpe du poème. Notes sur les origines sacrificielles de la poétique grecque." Poétique 58.215-232.

Svenbro, J. 1993. Phrasikleia: An Anthropology of Reading in Ancient Greece. Translation by J. Lloyd of Phrasikleia: Anthropologie de la lecture en Grèce ancienne (Paris 1988), with additions by the author. Ithaca.

Tambiah, S. J. 1985. Culture, Thought, and Social Action: An Anthropological Perspective. Cambridge, Mass.

Todorov, Tz. 1978. Les Genres du discours. Paris.

Todorov, Tz. 1990. Genres in Discourse. Translation by C. Porter of Todorov 1978. Cambridge.

Urios-Aparisi, E. 1993. “Anacreon: Love and Poetry (on 358 PMG, 13 Gentili).” Quaderni Urbinati di Cultura Classica 44:51-70.

Vetta, M., ed. 1983. Poesia e simposio nella Grecia antica: Guida storica e critica. Rome and Bari.

Williams, G. 1968. Tradition and Originality in Roman Poetry. Oxford.

Yerly, Ch. 1992. “Figures du tyran archaïque: Entre le monstre et le sage.” Etudes de Lettres: Revue de la Faculté des Lettres, Université de Lausanne 1992: 3-32. 